\title{
Prosorhynchus maternus sp. n. (Digenea: Bucephalidae) from the Malabar grouper Epinephelus malabaricus (Perciformes: Serranidae) off New Caledonia
}

\author{
Rodney A. Bray ${ }^{1}$ and Jean-Lou Justine ${ }^{2}$ \\ ${ }^{1}$ Department of Zoology, Natural History Museum, Cromwell Road, London SW7 5BD, UK; \\ ${ }^{2}$ Équipe Biogéographie Marine Tropicale, Unité Systématique, Adaptation, Évolution (CNRS, UPMC, MNHN, IRD), Institut de \\ Recherche pour le Développement, BP A5, 98848 Nouméa Cedex, Nouvelle Calédonie
}

Key words: Digenea, Bucephalidae, Prosorhynchus, Serranidae, Epinephelus, New Caledonia

\begin{abstract}
A new species, Prosorhynchus maternus sp. n., is described from the serranid fish Epinephelus malabaricus (Bloch et Schneider) in the waters off New Caledonia. It belongs to a group of Prosorhynchus species from serranids in which the uterus is restricted to the postovarian region. Its distinguishing features include the vitellarium relatively distant from the rhynchus, the cirrus-sac relatively distant from the posterior testis, the distinctly pre-equatorial mouth and several other somatic ratios. New records of Prosorhynchus longisaccatus Durio et Manter, 1968 from Epinephelus cyanopodus (Richardson) and Prosorhynchoides lamprelli Bott et Cribb, 2005 from Caranx papuensis Alleyne et Macleay off New Caledonia are also included.
\end{abstract}

There are over 70 named species of Prosorhynchus Odhner, 1905, about 60 of which are marine and about 10 are from freshwaters of China (e.g. Pan 1988), southeastern Asia (Moravec and Sey 1989) and south America (e.g. Thatcher 1999). As pointed out by Cribb et al. (2002), 13 of the marine species are found in members of the fish family Serranidae, particularly in the subfamily Epinephelinae. Some hosts were not fully identified and Cribb et al. (2002) did not consider the parasites from these. We have detected some 16 species reported in what are definitively or probably epinephelines. These are P. atlanticus Manter, 1940, P. bulbosus Kohn, 1961, P. caudovatus Manter, 1940, P. chorinemi Yamaguti, 1952, P. epinepheli Yamaguti, 1939, $P$. freitasi Nagaty, 1937, P. gonoderus Manter, 1940, P. jupe (Kohn, 1967), P. longisaccatus Durio et Manter, 1968, P. mcintoshi (Velasquez, 1959), P. ozakii Manter, 1934, P. pacificus Manter, 1940, P. platycephali (Yamaguti, 1934), P. promicropsi Manter, 1940, P. serrani Durio et Manter, 1968, and $P$. thapari Manter, 1953 (Manter 1934, 1940a, b, 1953, Yamaguti 1934, 1939, 1952, Nagaty 1937, Velasquez 1959, Kohn 1961, 1967, Durio and Manter 1968). Most of these species have been reported from individual host species or a few closely related hosts. Some, such as $P$. chorinemi and $P$. platycephali, were originally reported from other host groups. In this study we describe a new species from an epinepheline in the waters of the Coral Sea off New Caledonia. It is clearly related to a group of species from related hosts, but has a suite of distinctive features.

Seven species of bucephalids are known from the waters around New Caledonia. Durio and Manter (1968) reported Myorhynchus pritchardae Durio et Manter,
1968 from an unknown serranid, Neidhartia coronata Durio et Manter, 1968 from Epinephelus sp., Prosorhynchus freitasi from Epinephelus sp., P. longisaccatus from an unknown serranid and Prosorhynchus serrani from the yellow-edged lyretail Variola louti (Forsskål). We (new record) have found Prosorhynchoides lamprelli Bott et Cribb, 2005 (see below). The seventh species is that described below.

\section{MATERIALS AND METHODS}

A large wounded E. malabaricus (local name "mère loche") was noticed by divers off Nouméa, New Caledonia. The wound affected all the upper jaw and prevented the fish from eating; it was decided to kill the animal and use it for parasitological research. The fish was spear fished and immediately brought back to the laboratory, photographed and measured (fork length $1,280 \mathrm{~mm}$, weight $45 \mathrm{~kg}$ ). As predicted from the wound, the digestive tract was empty of food. Digeneans were collected alive, immediately fixed in hot seawater then transferred to ethanol.

Whole-mounts were stained with Mayer's paracarmine, cleared in beechwood creosote and mounted in Canada balsam. Measurements were made through a drawing tube on an Olympus BH-2 microscope, using a Digicad Plus digitising tablet and Carl Zeiss KS100 software adapted by Imaging Associates, and are quoted in micrometres, with the range and the mean in parentheses (Table 1). The following abbreviations are used: BMNH, the British Museum (Natural History) Collection at the Natural History Museum, London, UK; IPASCR, Institute of Parasitology, Academy of Sciences of the Czech Republic, České Budějovice; MNHN, Muséum National d'Histoire Naturelle, Paris; USNPC, United States National Parasite Collection, Beltsville. 
For purposes of comparison, various measurements and ratios were extracted from the literature. Where measurements were available, the range of ratios were estimated by dividing the shortest measurement of the organ in question by the shortest body length and the similarly for the longest measurements of organ and body length. Some measurements were estimated from those illustrations with scale bars and ratios estimated from these or directly from the illustrations.

\section{RESULTS}

Family B u cephalida e Poche

Subfamily Pros or hy c hin a e Nicoll

Genus Prosorhynchus Odhner

\section{Prosorhynchus maternus sp. n.}

Figs. 1-4

Description (based on 8 whole-mount preparations). Measurements and ratios in Table 1. Body elongate, widest at level of anterior part of vitellarium, distinctly narrowing immediately posterior to widest part of rhynchus (Figs. 1, 2). Tegument spinous; spines squamous, tiny, reach to posterior extremity. Rhynchus elongate, with about 5-6 muscular lobes around anterior rim, narrows posteriorly, strongly muscular, with patches of embedded gland-cells (Fig. 3). Mouth at level of ovary and/or anterior testis, well inside anterior half of body. Pharynx globular. Caecum oval, reaching anteriorly to level of anterior part of vitellarium.

Testes 2, oval, in posterior part of anterior half of body, slightly separated, contiguous or slightly overlapping. Cirrus-sac elongate, parallel sided, never reaching posterior testis. Seminal vesicle large, elongate-oval, in proximal cirrus-sac. Pars prostatica long, in 2 distinct parts; proximal part (seminal duct) coiled at level of seminal vesicle, with few gland-cells; distal part, wider, straight, surrounded by dense layer of gland-cells, lining of 2 types, proximal region lined with anuclear cell-like bodies, distal region lined with filaments in chevron arrangement pointing distally (Fig. 4). Ejaculatory duct narrow, short, opening on knobbly genital lobe, inside genital atrium. Genital atrium large. Genital pore distinctly separated from posterior extremity; in one case spermatophore seen extruded through pore (Fig. 1).

Ovary oval, mainly antero-lateral to anterior testis (6 specimens), may be lateral (1) or postero-lateral (1) to anterior testis. Uterine seminal vesicle just posterior to ovary. Laurer's canal not seen. Uterus fills most of postovarian region, does not reach anteriorly beyond ovary. Eggs numerous, tanned, operculate. Metraterm not detected, obscured by eggs. Vitellarium consists of 2 lateral fields of follicles, usually symmetrical (Fig. 2), or with one field offset (Fig. 1), anterior extremity distinctly posterior to rhynchus, but always anterior to caecum, gonads and uterus; posterior extremity at about level of posterior testis.

Excretory pore terminal; anterior extent of vesicle obscured by eggs.
T y p e hos t: Epinephelus malabaricus (Bloch et Schneider), Serranidae, Malabar grouper.

$\mathrm{S}$ i t e : Intestine.

T y p e 1 o c a 1 it y : Nouméa, off Ouen Toro, New Caledonia $\left(22^{\circ} 19^{\prime} \mathrm{S}, 166^{\circ} 27^{\prime} \mathrm{E}, 18 . \mathrm{v} .2005\right)$.

Prevalence : $1 / 1$.

Intensity: 8 .

D e p o s ition of s p e c i m e n s : holotype MNHN JNC1536D 01, paratypes, MNHN1536D 02-04, BMNH 2006.4.27.14-16. IPASCR D-596.

E t y m o 1 o g y : This refers to the local name of the host, "mère loche" or mother grouper, probably referring to the fact that it is large enough to be the mother of all groupers.

Remarks. Cribb et al. (2002) reckoned that there were 13 species of Prosorhynchus reported from epinepheline serranids and this figure now stands at 16 (see above). Prosorhynchus maternus belongs to a group of species which share the character of the uterus being restricted to the post-ovarian region, a relatively unusual feature in this genus. Other members of this group are P. atlanticus Manter, 1940, P. bulbosus Kohn, 1961, $P$. gonoderus Manter, 1940, P. longicollis Yamaguti, 1953, P. mcintoshi (Velasquez, 1959), P. pacificus Manter, 1940 and P. promicropsi Manter, 1940. Of parasites of non-epinephelines only $P$. mizellei Kruse, 1977 from the smooth lumpsucker, the cyclopterid Aptocyclus ventricosus (Pallas), in the Bering Sea and P. kahala Yamaguti, 1970 from the great amberjack, the carangid Seriola dumerili (Risso) have this character (Yamaguti 1970, Kruse 1977).

The only species so far reported from Epinephelus malabaricus is $P$. pacificus (or its putative synonym $P$. atlanticus). These records are by Hafeezullah and Siddiqi (1970) from Karwar, India and Leong and Wong (1988, 1990) from juvenile E. malabaricus imported from the Philippines for culture in Malaysia. The present form is close to P. pacificus, which was originally described by Manter (1940a) from the epinephelines, the sailfin grouper Mycteroperca olfax Jenyns and the broomtail grouper $M$. xenarcha Jordan, along with unidentified groupers, off various Galapagos Islands. Having examined USNPC slide No. 9326 labelled 'type', which bears three specimens, two of which are measurable (see Table 1), we consider that $P$. maternus differs from $P$. pacificus in the following features (see Table $1)$. The mouth is relatively further anterior, the vitellarium and caecum are also relatively closer to the anterior extremity and the testes are relatively further from the posterior extremity. The rhynchus is relatively smaller. The cirrus-sac is relatively smaller and never reaches even close to the posterior testis, whereas in $P$. pacificus the cirrus-sac overlaps the posterior testis in $68 \%$ of the specimens (Manter 1940a) and in two of the three specimens on the 'type' slide. In the one specimen where the cirrus-sac does not reach the posterior testis, it is very close (Table 1). Hafeezullah and Siddiqi (1970) gave an illustration of the worm they found in 

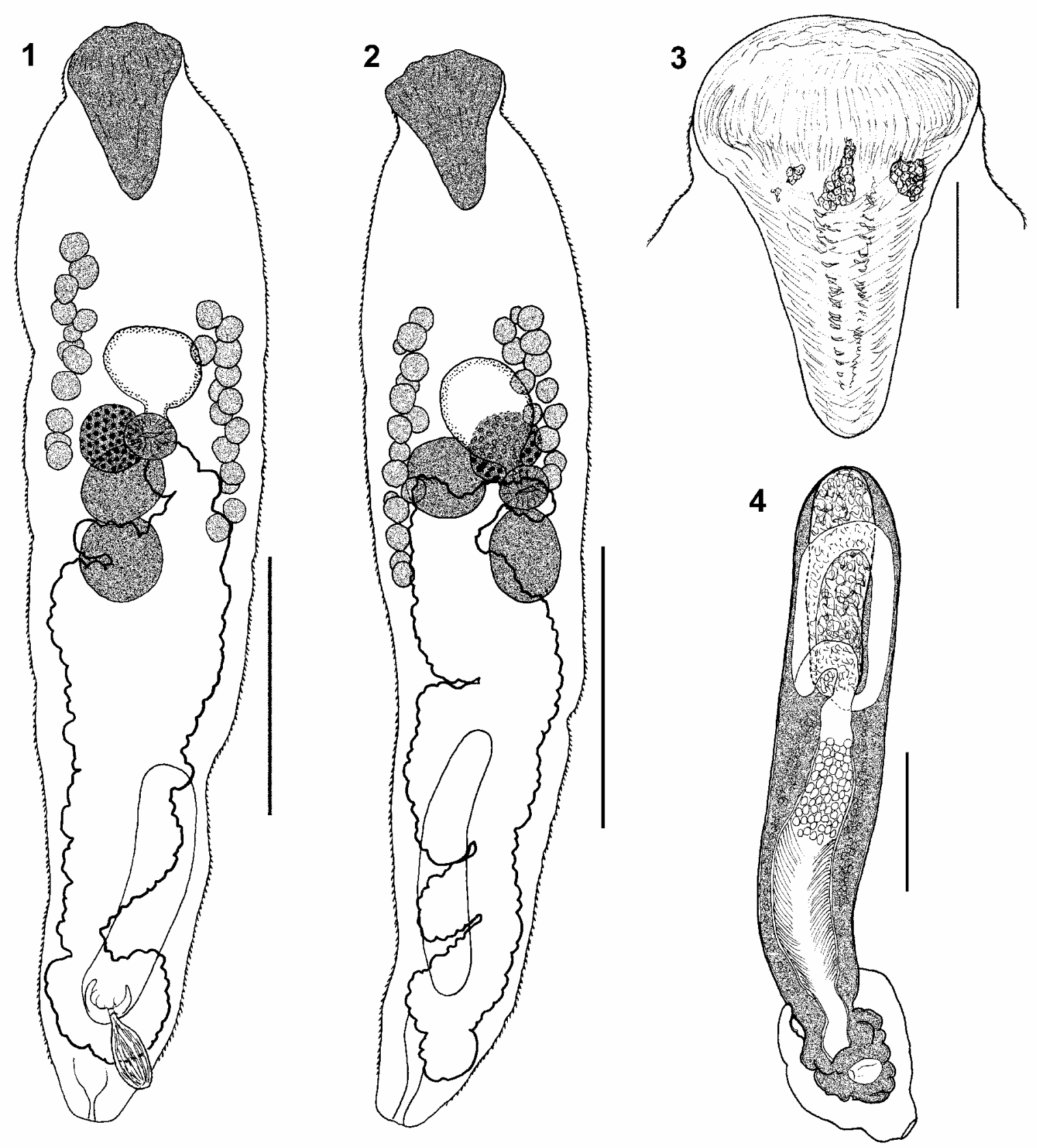

Figs. 1-4. Prosorhynchus maternus sp. n. Fig. 1. Holotype, ventral view, uterus in bold outline and treated as transparent, cirrussac in outline, note spermatophore. Fig. 2. Paratype, ventral view, uterus in bold outline and treated as transparent, cirrus-sac in outline. Fig. 3. Rhynchus, showing embedded gland-cells. Fig. 4. Cirrus-sac and genital atrium, with egg in atrium. Scale bars: Figs. 1, $2=500 \mu \mathrm{m}$; Figs. 3, $4=100 \mu \mathrm{m}$.

E. malabaricus and called P. atlanticus, and some data can be gleaned from it (Table 1). It appears more similar to our specimens than does the original description of the species. Winter (1960) described P. pacificus from the spotted grouper Epinephelus analogus Gill from the Pacific Ocean off Sinaloa, Mexico. The illustration is in the form of a microphotograph which gives no useful information, but the description is quite detailed and suggests that this form differs from $P$. maternus in its more posterior mouth, larger cirrus-sac and larger eggs (Table 1). All the above descriptions give a greater relative width than in $P$. maternus, but this may be due in most cases to flattening. 
Table 1. Measurements of various Prosorhynchus species. Major ratios and some measurements differentiating worms from $P$. maternus sp.n. are emboldened. Measurements and ratios estimated from published dimensions or illustrations are in brackets.

\begin{tabular}{|c|c|c|c|c|}
\hline Species & P. maternus sp. n. & P. pacificus & P. atlanticus & P. pacificus \\
\hline Source & Present study & $\begin{array}{l}\text { USNPC 9326, } \\
\text { types }\end{array}$ & $\begin{array}{l}\text { Hafeezullah and } \\
\text { Siddiqi (1970) }\end{array}$ & Winter (1960) \\
\hline Host(s) & $\begin{array}{l}\text { Epinephelus } \\
\text { malabaricus }\end{array}$ & $\begin{array}{l}\text { Mycteroperca } \\
\text { olfax }\end{array}$ & $\begin{array}{l}\text { Epinephelus } \\
\quad \text { malabaricus }\end{array}$ & $\begin{array}{l}\text { Epinephelus } \\
\text { analogus }\end{array}$ \\
\hline $\begin{array}{l}\text { Locality } \\
\mathrm{n}\end{array}$ & $\begin{array}{l}\text { New Caledonia } \\
8\end{array}$ & $\begin{array}{l}\text { Albemarle Is., } \\
\text { Galapagos } \\
2\end{array}$ & $\begin{array}{l}\text { off Karwar, } \\
\text { India } \\
{[1]}\end{array}$ & $\begin{array}{l}\text { off Pacific coast, } \\
\text { Mexico } \\
5\end{array}$ \\
\hline Length & $2,052-2,227(2,142)$ & $1,232-1,359$ & {$[1,359]$} & $1,554-1,887$ \\
\hline Width & $392-476(438)$ & $350-367$ & {$[335]$} & $459-592$ \\
\hline Pre-vitelline distance & 409-477 (441) & $313-414$ & {$[388]$} & $281-444$ \\
\hline Pre-caecal distance & $497-604(552)$ & $366-450$ & [441] & \\
\hline Pre-uterine distance & 739-922 (818) & $509-631$ & {$[741]$} & \\
\hline Pre-mouth distance & $788-870(833)$ & $590-624$ & [653] & $757-808$ \\
\hline Pre-testicular distance & $665-816(745)$ & $427-623$ & {$[565]$} & \\
\hline Pre-ovarian distance & $633-762(712)$ & $421-562$ & [441] & \\
\hline Rhynchus & $\begin{array}{l}280-360 \times 189- \\
243(317 \times 219)\end{array}$ & $\begin{array}{l}239-242 \times \\
211-211 \\
\end{array}$ & {$[208 \times 157]$} & $\begin{array}{l}{[259-278 \times} \\
210-292]\end{array}$ \\
\hline Rhynchus to vitellarium & $77-186(125)$ & $98-180$ & [173] & \\
\hline Rhynchus to uterus & $386-641(510)$ & $277-396$ & [547] & \\
\hline Rhynchus to caecum & $142-330(243)$ & $126-212$ & {$[238]$} & \\
\hline Long vitelline field & $475-606(545)$ & $252-342$ & [327] & $407-422$ \\
\hline Number of follicles in above & $14-17(15.5)$ & $13-14$ & & \\
\hline Short vitelline field & $360-512(445)$ & $233-245$ & [300] & $296-392$ \\
\hline Number of follicles in above & $12-15(13.1)$ & $13-15$ & & \\
\hline Caecum & $\begin{array}{l}202-231 \times 134- \\
178(214 \times 152)\end{array}$ & $\begin{array}{l}99-125 \times \\
142-199 \\
\end{array}$ & {$[194 \times 106]$} & $\begin{array}{l}252-296 \times \\
206-275\end{array}$ \\
\hline Pharynx & $\begin{array}{l}58-101 \times 69- \\
100(80 \times 87)\end{array}$ & $\begin{array}{l}56-69 \times \\
61-62\end{array}$ & {$[62 \times 62]$} & 69-103 diam. \\
\hline Ovary & $\begin{array}{l}127-153 \times 98- \\
131(140 \times 118)\end{array}$ & $\begin{array}{l}96-98 \times \\
119-129 \\
\end{array}$ & {$[86 \times 86]$} & $\begin{array}{l}112-138 \times \\
105-120\end{array}$ \\
\hline Ovary to anterior testis & $0-12(2)$ & 0 & {$[0]$} & \\
\hline Anterior testis & $\begin{array}{l}152-188 \times 124- \\
160(172 \times 147)\end{array}$ & $\begin{array}{l}104-107 \times \\
141-151\end{array}$ & {$[132 \times 106]$} & $177-188 \times 138$ \\
\hline Distance between testes & $0-114(49)$ & $0-30$ & [39] & \\
\hline Posterior testis & $\begin{array}{l}152-191 \times 117- \\
148(166 \times 131)\end{array}$ & $\begin{array}{l}83-100 \times \\
149-159\end{array}$ & {$[122 \times 106]$} & $189 \times 138$ \\
\hline Posterior testis to cirrus-sac & $230-363(281)$ & 0-37 & {$[124]$} & \\
\hline Cirrus-sac & $\begin{array}{l}468-541 \times 91- \\
116(499 \times 102)\end{array}$ & $\begin{array}{l}428-464 \times \\
114-118\end{array}$ & {$[309 \times 53]$} & $\begin{array}{l}482-671 \times \\
102-129\end{array}$ \\
\hline Seminal vesicle & $\begin{array}{l}198-275 \times 61- \\
88(233 \times 72)\end{array}$ & $\begin{array}{l}150-212 \times \\
30-41\end{array}$ & {$[106 \times ?]$} & \\
\hline Pars prostatica & $\begin{array}{l}181-291 \times 49- \\
90(222 \times 65)\end{array}$ & $\begin{array}{l}244-245 \times \\
63-64\end{array}$ & {$[168 \times 53]$} & \\
\hline Post-testicular region & $982-1,143(1,045)$ & $512-605$ & [530] & \\
\hline Post-vitelline region & $1,022-1,203(1,110)$ & $606-671$ & [627] & \\
\hline $\begin{array}{l}\text { Anterior extremity of cirrus-sac to } \\
\text { posterior extremity (AECSPE) }\end{array}$ & $695-837(775)$ & $591-595$ & [420] & $929-1,075$ \\
\hline Post-ovarian region & $1,190-1,374(1,267)$ & $693-721$ & [759] & \\
\hline Genital pore to posterior extremity & $198-288(230)$ & $96-178$ & {$[122]$} & $234-279$ \\
\hline Post-uterine region & $105-161(128)$ & $66-98$ & & \\
\hline Eggs & $\begin{array}{l}27-28 \times 14- \\
22(28 \times 19)\end{array}$ & $\begin{array}{l}28-31 \times \\
15-16\end{array}$ & & $\begin{array}{l}29-33 \times \\
19-20\end{array}$ \\
\hline Width\%* & $17.7-22.2(20.4)$ & $25.8-29.8$ & [24.7] & [29.5-31.4] \\
\hline Pre-vitelline distance $\% *$ & $18.8-23.2(20.6)$ & $25.8-30.5$ & [28.6] & {$[18.1-23.5]$} \\
\hline Pre-caecal distance $\% *$ & $23.1-28.0(25.8)$ & $29.7-33.1$ & [32.5] & \\
\hline Pre-uterine distance $\% *$ & $34.4-41.4(38.2)$ & $41.3-46.4$ & [54.5] & \\
\hline
\end{tabular}


Table 1. Continued.

\begin{tabular}{|c|c|c|c|c|}
\hline Pre-mouth distance $\% *$ & $37.7-39.6(38.6)$ & $45.9-47.9$ & [48.1] & {$[48.7-42.8]$} \\
\hline Pre-testicular distance $\% *$ & $30.6-38.0(34.8)$ & $34.7-45.8$ & [41.6] & \\
\hline Pre-ovarian distance $\% *$ & $29.4-35.1(33.3)$ & $34.2-41.3$ & {$[32.5]$} & \\
\hline Rhynchus length\%* & $12.6-16.7(14.8)$ & $17.8-19.4$ & {$[15.3]$} & {$[16.6-14.7]$} \\
\hline $\begin{array}{l}\text { Rhynchus width as \% rhynchus } \\
\text { length }\end{array}$ & $65.2-85.7(69.5)$ & $87.0-88.3$ & {$[75.5]$} & [75.5-105] \\
\hline Long vitelline field $\% *$ & $22.0-28.2(25.5)$ & $18.5-27.7$ & {$[24.1]$} & {$[26.2-22.4]$} \\
\hline Caecal length\%* & $9.32-10.5(10.0)$ & $7.31-10.2$ & [14.3] & {$[16.2-15.7]$} \\
\hline Ovary length\%* & $5.83-7.27(6.54)$ & $7.08-7.93$ & [6.33] & [7.21-7.31] \\
\hline Anterior testis length $\% *$ & $7.29-8.68(8.02)$ & $7.65-8.65$ & {$[9.71]$} & {$[11.4-9.96]$} \\
\hline Distance between testes $\% *$ & $0-5.24(2.30)$ & $0-2.23$ & {$[2.87]$} & \\
\hline Posterior testis length $\% *$ & $7.07-9.19(7.75)$ & $6.72-7.37$ & {$[8.98]$} & \\
\hline Posterior testis to cirrus-sac $\% *$ & $10.3-16.9(13.1)$ & 0-3.01 & {$[9.12]$} & \\
\hline Cirrus-sac length $\% *$ & $21.6-24.5(23.3)$ & 31.5-37.7 & {$[22.7]$} & {$[31.0-35.6]$} \\
\hline $\begin{array}{l}\text { Seminal vesicle length as \% of } \\
\text { cirrus-sac length }\end{array}$ & $37.7-58.8(46.9)$ & $35.0-45.8$ & {$[34.3]$} & \\
\hline Post-testicular region $\% *$ & $45.2-53.1(48.8)$ & $37.6-49.1$ & [39.0] & \\
\hline Post-vitelline region $\% *$ & $48.8-55.4(51.8)$ & $49.2-49.4$ & {$[46.1]$} & \\
\hline AECSPE\%* & $32.4-39.0(36.2)$ & $43.8-48.0$ & [30.9] & [59.8-57.0] \\
\hline Post-ovarian region $\% *$ & $56.9-63.9(59.2)$ & $51.0-58.5$ & {$[55.8]$} & \\
\hline $\begin{array}{l}\text { Genital pore to posterior } \\
\text { extremity\%* }\end{array}$ & $9.17-13.8(10.8)$ & $7.80-13.1$ & [8.98] & {$[15.1-18.0]$} \\
\hline Post-uterine region $\% *$ & $4.75-7.49(5.97)$ & $4.84-7.98$ & & \\
\hline
\end{tabular}

$*$ as $\%$ of body-length

Table 1. Continued.

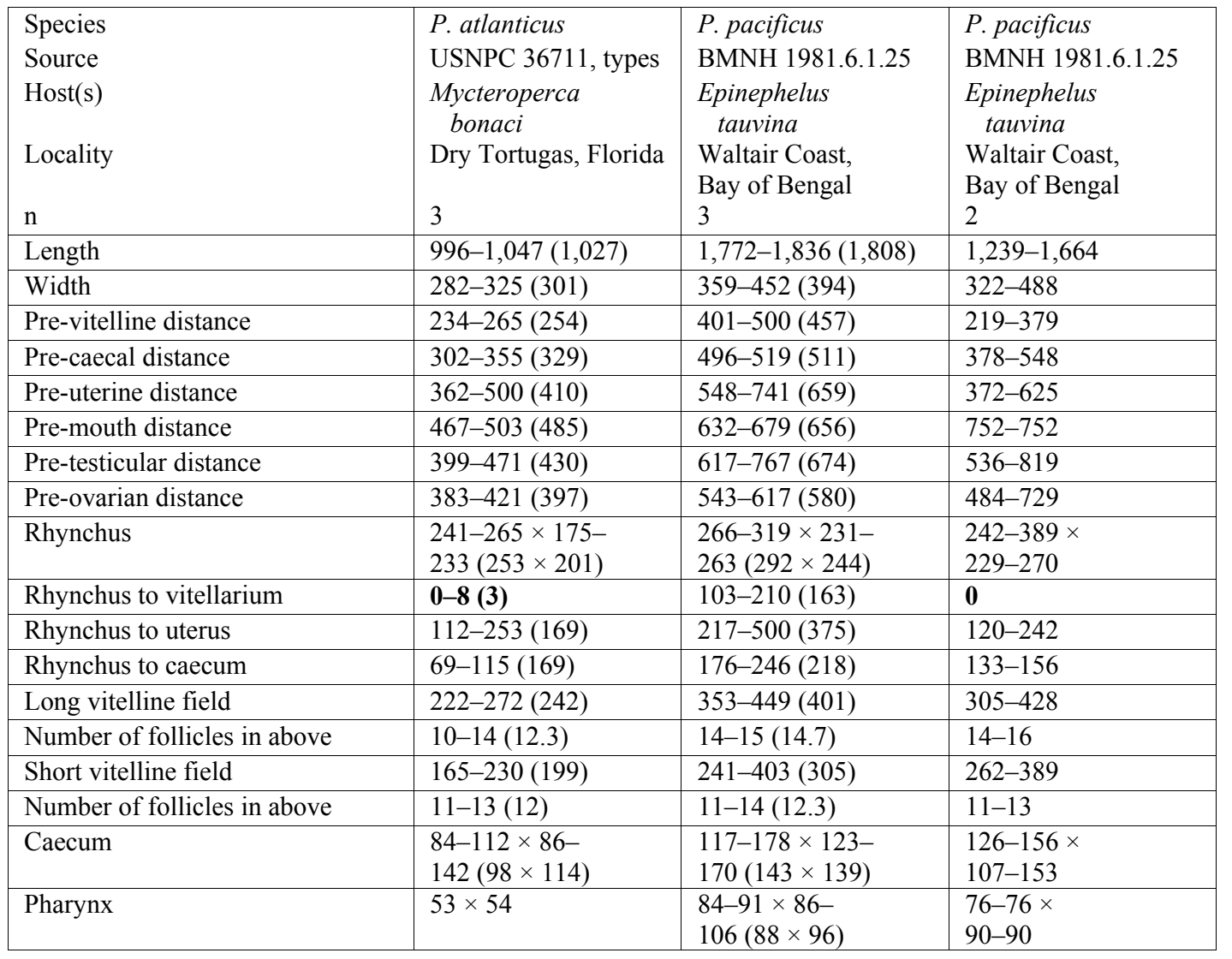


Table 1. Continued.

\begin{tabular}{|c|c|c|c|}
\hline Species & P. atlanticus & P. pacificus & P. pacificus \\
\hline Source & USNPC 36711 , types & BMNH 1981.6.1.25 & BMNH 1981.6.1.25 \\
\hline Host(s) & $\begin{array}{l}\text { Mycteroperca } \\
\text { bonaci }\end{array}$ & $\begin{array}{l}\text { Epinephelus } \\
\text { tauvina }\end{array}$ & $\begin{array}{l}\text { Epinephelus } \\
\text { tauvina }\end{array}$ \\
\hline $\begin{array}{l}\text { Locality } \\
\mathrm{n}\end{array}$ & $\begin{array}{l}\text { Dry Tortugas, Florida } \\
3\end{array}$ & $\begin{array}{l}\text { Waltair Coast, } \\
\text { Bay of Bengal } \\
3\end{array}$ & $\begin{array}{l}\text { Waltair Coast, } \\
\text { Bay of Bengal } \\
2\end{array}$ \\
\hline Ovary & $\begin{array}{l}80-90 \times 71- \\
115(84 \times 88)\end{array}$ & $\begin{array}{l}104 \times 89- \\
91(104 \times 90)\end{array}$ & $\begin{array}{l}79-98 \times \\
68-97\end{array}$ \\
\hline Ovary to anterior testis & 0 & $8-9(8)$ & 0 \\
\hline Anterior testis & $\begin{array}{l}92-121 \times 79- \\
132(105 \times 101)\end{array}$ & $\begin{array}{l}112-143 \times 97- \\
131(126 \times 115)\end{array}$ & $\begin{array}{l}111-137 \times \\
94-130\end{array}$ \\
\hline Distance between testes & $0-40(13)$ & $8-72(47)$ & $7-26$ \\
\hline Posterior testis & $79 \times 88$ & $\begin{array}{l}108-122 \times 78- \\
119(115 \times 98)\end{array}$ & $\begin{array}{l}87-123 \times \\
82-117\end{array}$ \\
\hline Posterior testis to cirrus-sac & 0-10 (3) & $167-324(242)$ & 0-25 \\
\hline Cirrus-sac & $\begin{array}{l}288-314 \times 86- \\
92(298 \times 89)\end{array}$ & $\begin{array}{l}416-480 \times 96-120 \\
(446 \times 107)\end{array}$ & $\begin{array}{l}424-481 \times \\
84-136\end{array}$ \\
\hline Seminal vesicle & $\begin{array}{l}107-155 \times 19- \\
25(133 \times 23)\end{array}$ & $\begin{array}{l}192-271 \times 46- \\
59(230 \times 53)\end{array}$ & $\begin{array}{l}187-201 \times \\
41-82\end{array}$ \\
\hline Pars prostatica & $\begin{array}{l}185-216 \times 49 \\
56(201 \times 52)\end{array}$ & $\begin{array}{l}165-215 \times 40 \\
58(198 \times 52)\end{array}$ & $\begin{array}{l}179-222 \times \\
45-86\end{array}$ \\
\hline Post-testicular region & $398-458(428)$ & $826-976(898)$ & $484-710$ \\
\hline Post-vitelline region & $442-551(504)$ & $884-968(932)$ & $739-813$ \\
\hline $\begin{array}{l}\text { Anterior extremity of cirrus-sac to } \\
\text { posterior extremity (AECSPE) }\end{array}$ & $377-434(408)$ & $642-721(674)$ & $546-687$ \\
\hline Post-ovarian region & $549-566(556)$ & $1,063-1,176(1,120)$ & $676-916$ \\
\hline Genital pore to posterior extremity & $83-172(127)$ & $228-271(255)$ & $137-181$ \\
\hline Post-uterine region & $15-28(22)$ & $112-155(127)$ & $114-115$ \\
\hline Eggs & $\begin{array}{l}31-36 \times 18- \\
20(34 \times 19)\end{array}$ & $\begin{array}{l}31-33 \times 18- \\
20(32 \times 19)\end{array}$ & $\begin{array}{l}34-38 \times \\
21-24\end{array}$ \\
\hline Width\%* & $26.9-32.7(29.3)$ & $19.7-24.6(21.8)$ & $26.0-29.3$ \\
\hline Pre-vitelline distance $\% *$ & $23.4-25.4(24.8)$ & $22.6-27.2(25.2)$ & $17.7-22.8$ \\
\hline Pre-caecal distance $\% *$ & 30.3-33.9 (32.0) & $27.0-29.3(28.3)$ & 30.5-32.9 \\
\hline Pre-uterine distance $\% *$ & $35.6-47.8(39.9)$ & $29.8-40.8(36.5)$ & $30.0-37.5$ \\
\hline Pre-mouth distance $\% *$ & $44.6-48.5(46.6)$ & $35.7-37.4(36.5)$ & $45.2-45.2$ \\
\hline Pre-testicular distance $\% *$ & $40.1-44.9(41.8)$ & $33.6-42.2(37.3)$ & $43.3-49.2$ \\
\hline Pre-ovarian distance $\% *$ & $37.0-40.2(38.7)$ & $29.6-34.8(32.2)$ & $39.0-43.8$ \\
\hline Rhynchus length\%* & $24.1-25.6(24.6)$ & $14.6-17.4(16.1)$ & $19.5-23.4$ \\
\hline Rhynchus width as \% rhynchus length & $69.2-92.8(79.9)$ & 74.4-99.1 (84.4) & $69.7-94.6$ \\
\hline Long vitelline field $\% *$ & $21.2-27.3(23.6)$ & $19.9-24.5(22.1)$ & $24.6-25.7$ \\
\hline Caecal length\%* & $8.04-11.3(9.66)$ & $6.59-9.71(7.91)$ & $9.37-10.2$ \\
\hline Ovary length $\% *$ & $7.61-8.65(8.22)$ & $5.67-5.85(5.78)$ & $5.88-6.40$ \\
\hline Anterior testis length $\% *$ & $8.75-12.2(10.3)$ & $6.16-7.81(6.95)$ & $8.21-8.94$ \\
\hline Distance between testes\%* & $0-3.86(1.29)$ & $0.42-4.09(2.62)$ & $0.41-2.12$ \\
\hline Posterior testis length $\% *$ & 7.53 & $5.94-6.63(6.38)$ & $7.05-7.38$ \\
\hline Posterior testis to cirrus-sac\%* & $0-0.92(0.31)$ & $9.42-17.7(13.3)$ & 0-1.50 \\
\hline Cirrus-sac length $\% *$ & $27.5-30.3(29.0)$ & $22.9-27.1(24.7)$ & $28.9-34.2$ \\
\hline $\begin{array}{l}\text { Seminal vesicle length as \% of } \\
\text { cirrus-sac length }\end{array}$ & $36.7-49.3(44.5)$ & $46.1-61.2(51.5)$ & $41.9-44.2$ \\
\hline Post-testicular region $\% *$ & $38.0-44.2(41.1)$ & $45.5-53.2(49.7)$ & $39.1-42.7$ \\
\hline Post-vitelline region $\% *$ & $42.2-53.2(49.1)$ & $48.2-54.6(51.6)$ & $48.9-59.7$ \\
\hline AECSPE\%* & $36.0-41.9(39.8)$ & $35.3-40.7(37.3)$ & $41.3-44.1$ \\
\hline Post-ovarian region $\% *$ & $52.4-55.4(54.2)$ & $60.0-64.1(62.0)$ & $54.6-55.1$ \\
\hline $\begin{array}{l}\text { Genital pore to posterior } \\
\text { extremity\%* }\end{array}$ & $8.32-16.6(12.3)$ & $12.4-15.1(14.1)$ & $19.9-11.1$ \\
\hline Post-uterine region $\% *$ & $1.46-2.71(2.19)$ & $6.10-8.52(6.99)$ & $6.85-9.29$ \\
\hline
\end{tabular}

$*$ as $\%$ of body-length 
Madhavi (1974) reported, but did not describe, $P$. pacificus from the greasy grouper Epinephelus tauvina (Forsskål) in the Bay of Bengal. She gave eggmeasurements $(27-33 \times 16-20 \mu \mathrm{m})$, but no other data. We have examined five of her specimens (BMNH 1981.6.1.25) and two distinct species appear to be present. Three specimens are similar to our form and may well be conspecific, whereas two differ in the vitellarium reaching the rhynchus, the cirrus-sac reaching to or almost to the posterior testis and in several other ratios (Table 1).

Prosorhynchus pacificus has also been reported in the lutjanid John's snapper Lutjanus johni Bloch, off Malaysia (Leong and Wong 1989). There are several reports of $P$. pacificus in the Atlantic Ocean resulting, no doubt, from the synonymy discussed below. These records need confirmation.

Hanson (1950) considered $P$. atlanticus a synonym of P. pacificus, and Winter (1960), Overstreet (1969) and Madhavi (1974) agreed, whereas Nahhas and Cable (1964) did not. We have examined the USNPC slide No. 36711 of $P$. atlanticus labelled 'type' and have measured the three specimens (Table 1). This species differs from $P$. maternus in that the vitellarium reaches to or almost to the rhynchus, the cirrus-sac reaches to or almost to the posterior testis, the mouth is more posterior, the rhynchus relatively longer, the cirrus-sac is relatively larger and several other ratios do not overlap (Table 1). The synonymy of $P$. atlanticus and P. pacificus is not supported by our measurements in that in the former the vitellarium reaches to or close to the rhynchus, the rhynchus is relatively longer, the cirrus-sac is relatively shorter and the eggs are larger (Table 1).

Madhavi (1974) also considered P. luzonicus Velasquez, 1959, from the barramundi Lates calcarifer (Bloch) (Latidae) from off of the Philippines, a synonym of $P$. pacificus. Prosorhynchus luzonicus differs from $P$. maternus in that the vitellarium reaches almost to the rhynchus and the cirrus-sac reaches almost to the posterior testis.

Prosorhynchus gonoderus differs from P. maternus in the much more anterior position of the mouth, vitellarium and gonads (Manter 1940a).

Prosorhynchus longicollis differs from P. maternus in many features. It is much narrower, has a tiny buttonlike rhynchus, the mouth is well into the posterior third of the body, the testes are relatively close to the posterior extremity and the cirrus-sac overlaps the gonads as far as the ovary (Yamaguti 1953).

Other species differ from $P$. maternus in the following characters: In P. mcintoshi the cirrus-sac overlaps the posterior testis and the mouth is equatorial (Velasquez 1959). P. bulbosus, an Atlantic species, differs in being narrower, with a more posterior vitellarium, an equatorial mouth and testes in the posterior half of the body (Kohn 1961, Kohn 1967). P. promicropsi, an Atlantic species, differs in the much more posteriorly situated vitellarium, with the caecum reaching distinctly anterior to it, and the more posteriorly situated mouth and gonads (Manter 1940b). P. mizellei, from a cyclopterid, is a squat worm, with the relatively very large cirrus-sac reaching to the ovary, a small rhynchus and eggs 32-40 $\mu \mathrm{m}$ long (Kruse 1977). P. kahala, from a carangid, is an elongate worm, with all the gonads in the posterior half of the body, the mouth in the posterior quarter of the body and the cirrus-sac overlapping the anterior testis (Yamaguti 1970).

Prosorhynchus maternus can be readily distinguished from the other Prosorhynchus species reported from New Caledonia by its post-ovarian uterus and several other features. In P. freitasi the vitellarium reaches only to the equatorial level and most of the organs are crowded into the posterior half of the body, the rhynchus is relatively tiny and the cirrus-sac reaches to the posterior testis (Nagaty 1937). P. longisaccatus is a relatively squat worm, with a relatively large rhynchus, the vitellarium overlaps the rhynchus and the long cirrus-sac reaches almost to the equatorial level, overlapping the gonads. In $P$. serrani the uterus reaches into the previtelline region and the cirrus-sac overlaps the posterior testis (Durio and Manter 1968).

Further records of bucephalids from New Caledonia. We have found two further bucephalid species from epinepheline serranids from off New Caledonia. Prosorhynchus longisaccatus Durio et Manter, 1968, originally reported from the 'leche' has been found by us in the speckled blue grouper Epinephelus cyanopodus (Richardson) (MNHN JNC1659, BMNH 2006.4. 27.1-10). In New Caledonia E. cyanopodus is known as the 'loche bleue', being blue, and is readily identifiable. Durio and Manter (1968) used the name 'loche bleue' without the scientific binomial in several other descriptions, prompting us to think that the original report of this worm is from a different species of grouper. We have also found Prosorhynchoides lamprelli Bott et Cribb, 2005 from the brassy trevally Caranx papuensis Alleyne et Macleay, off Nouméa (MNHN JNC1189C, BMNH 2006.4.27.11-13) (see Bott and Cribb 2005).

Acknowledgements. We are grateful to Prof. Claude Chauvet (UNC, Université de Nouvelle-Calédonie, Nouméa) and Soazig Le Mouellic (UNC) for collecting of the fish on board the R/V 'Alcyon', Amandine Marie and Damien Hinsinger, students, for helping with parasitological examination, Angelo di Matteo (IRD) who provided technical help, Patricia Pilitt (USNPC, Beltsville, USA) for the loan of specimens and David Gibson (Natural History Museum, London) for reading the manuscript. 


\section{REFERENCES}

BOTT N.J., CRIBB T.H. 2005: Prosorhynchoides lamprelli $\mathrm{n}$. sp. (Digenea: Bucephalidae) from the brassy trevally, $\mathrm{Ca}$ ranx papuensis (Teleostei: Carangidae), from off Lizard Island on the Great Barrier Reef, Australia. Zootaxa 1059: 33-38.

CRIBB T.H., BRAY R.A., WRIGHT T., PICHELIN S. 2002: The trematodes of groupers (Serranidae: Epinephelinae): knowledge, nature and evolution. Parasitology 124: S23S42.

DURIO W.O., MANTER H.W. 1968: Some digenetic trematodes of marine fishes of New Caledonia. Part I. Bucephalidae, Monorchiidae, and some smaller families. Proc. Helminthol. Soc. Wash. 35: 143-153.

HAFEEZULLAH M., SIDDIQI A.H. 1970: Digenetic trematodes of marine fishes of India. Part I. Bucephalidae and Cryptogonimidae. Indian J. Parasitol. 22: 1-22.

HANSON M.L. 1950: Some digenetic trematodes of marine fishes of Bermuda. Proc. Helminthol. Soc. Wash. 17: 74 89.

KOHN A. 1961: Um novo Prosorhynchus parasito de Garrupa sp. (Trematoda, Bucephaliformes). Atas Soc. Biol. Rio de J. 5: 46-49.

KOHN A. 1967: Sôbre um nôvo gênero de Prosorhynchinae Nicoll, 1914 e novos dados sôbre Prosorhynchus bulbosus Kohn, 1961 e Rhipidocotyle quadriculatum Kohn, 1961 (Trematoda, Bucephaliformes). Mem. Inst. Oswaldo Cruz 65: 107-114.

KRUSE G.O.W. 1977: Some digenetic trematodes from fishes of the Bering Sea with the descriptions of Prosorhynchus mizellei sp. n. (Bucephalidae) and Pseudopecoelus nossamani sp. n. (Opecoelidae). Proc. Helminthol. Soc. Wash. 44: 73-76.

LEONG T.S., WONG S.Y. 1988: A comparative study of the parasite fauna of wild and cultured grouper (Epinephelus malabaricus Bloch et Schneider) in Malaysia. Aquaculture 68: 203-207.

LEONG T.S., WONG S.Y. 1989: Parasites of wild and cultured golden snapper, Lutjanus johni (Bloch), in Malaysia. Trop. Biomed. 6: 73-76.

LEONG T.S., WONG S.Y. 1990: Parasites of healthy and diseased juvenile grouper (Epinephelus malabaricus (Bloch and Schneider)) and seabass (Lates calcarifer (Bloch)) in floating cages in Penang, Malaysia. Asian Fish. Sci. 3: 319-327.

MADHAVI R. 1974: Digenetic trematodes from marine fishes of Waltair Coast, Bay of Bengal. Family Bucephalidae. Riv. Parassitol. 35: 189-199.

MANTER H.W. 1934: Some digenetic trematodes from deepwater fish of Tortugas, Florida. Pap. Tortugas Lab. 28: 257-345.
MANTER H.W. 1940a: Digenetic trematodes of fishes from the Galapagos Islands and the neighboring Pacific. Allan Hancock Pacif. Exped. 2: 325-497.

MANTER H.W. 1940b: Gasterostomes (Trematoda) of Tortugas, Florida. Pap. Tortugas Lab. 33: 1-19.

MANTER H.W. 1953: Two new species of Prosorhynchinae (Trematoda: Gasterostomata) from the Fiji Islands. In: J. Dayal and K. Singh (Eds.), Thapar, G.S., Commemoration Volume. University of Lucknow, Lucknow, pp. 193-200.

MORAVEC F., SEY O. 1989: Some trematodes of freshwater fishes from north Vietnam with a list of recorded endohelminthes by fish hosts. Folia Parasitol. 36: 243-262.

NAGATY H.F. 1937: Trematodes of fishes from the Red Sea. Part 1. Studies on the family Bucephalidae Poche, 1907. Egyptian University, Cairo, 172 pp.

NAHHAS F.M., CABLE R.M. 1964: Digenetic and aspidogastrid trematodes from marine fishes of Curaçao and Jamaica. Tulane Stud. Zool. 11: 169-228.

OVERSTREET R.M. 1969: Digenetic trematodes of marine teleost fishes from Biscayne Bay, Florida. Tulane Stud. Zool. Bot. 15: 119-176.

PAN H. 1988: Studies on digenetic trematodes of fam. Bucephalidae from freshwater fishes of Guangdong Province, with descriptions of two new species. Acta Hydrobiol. Sin. 12: 65-69. (In Chinese, English summary.)

THATCHER V.E. 1999: Two new Bucephalidae (Trematoda) from fishes of the Brazilian Amazon. Acta Amazon. 29: 331-335.

VELASQUEZ C.C. 1959: Studies on the family Bucephalidae Poche 1907 (Trematoda) from Philippine food fishes. J. Parasitol. 45: 135-147.

WINTER H.A. 1960: Algunos trematodos digeneos de peces marinos de aguas del Oceano Pacifico del sur de California, U.S.A. y del litoral Mexicano. An. Inst. Biol. Univ. Nac. Autón. Méx. 30: 183-208.

YAMAGUTI S. 1934: Studies on the helminth fauna of Japan. Part 2. Trematodes of fishes, I. Jpn. J. Zool. 5: 249-541.

YAMAGUTI S. 1939: Studies on the helminth fauna of Japan. Part 26. Trematodes of fishes, VI. Jpn. J. Zool. 8: 211230.

YAMAGUTI S. 1952: Parasitic worms mainly from Celebes. Part 1. New digenetic trematodes of fishes. Acta Med. Okayama 8: 146-198.

YAMAGUTI S. 1953: Parasitic worms mainly from Celebes. Part 3. Digenetic trematodes of fishes, II. Acta Med. Okayama 8: 257-295.

YAMAGUTI S. 1970: Digenetic trematodes of Hawaiian fishes. Keigaku Publishing Co., Tokyo, 436 pp.

Accepted 10 May 2006 